University of South Carolina

Scholar Commons

9-8-2006

\title{
Absorption Properties of a Porous Organic Crystalline Apohost Formed by a Self-Assembled Bis-Urea Macrocycle
}

\author{
Mahender B. Dewal \\ University of South Carolina - Columbia \\ Michael W. Lufaso \\ University of North Florida \\ Andrew D. Hughes \\ University of South Carolina - Columbia \\ Stevan A. Samuel \\ University of South Carolina - Columbia \\ Perry J. Pellechia \\ University of South Carolina - Columbia
}

See next page for additional authors

Follow this and additional works at: https://scholarcommons.sc.edu/chem_facpub

Part of the Chemistry Commons

Publication Info

Published in Chemistry of Materials, Volume 18, Issue 20, 2006, pages 4855-4864.

(c) Chemistry of Materials 2006, American Chemical Society.

This Article is brought to you by the Chemistry and Biochemistry, Department of at Scholar Commons. It has been accepted for inclusion in Faculty Publications by an authorized administrator of Scholar Commons. For more information, please contact digres@mailbox.sc.edu. 


\section{Author(s)}

Mahender B. Dewal, Michael W. Lufaso, Andrew D. Hughes, Stevan A. Samuel, Perry J. Pellechia, and Linda S. Shimizu 


\title{
Absorption Properties of a Porous Organic Crystalline Apohost Formed by a Self-Assembled Bis-Urea Macrocycle
}

\author{
Mahender B. Dewal, ${ }^{\dagger}$ Michael W. Lufaso,${ }^{\ddagger}$ Andrew D. Hughes,${ }^{\dagger}$ Stevan A. Samuel, ${ }^{\dagger}$ \\ Perry Pellechia, ${ }^{\dagger}$ and Linda S. Shimizu*, ${ }^{\dagger}$ \\ Department of Chemistry and Biochemistry, University of South Carolina, Columbia, \\ South Carolina 29208, and Department of Chemistry and Physics, University of North Florida, \\ Jacksonville, Florida 32224
}

\section{Received June 16, 2006. Revised Manuscript Received August 2, 2006}

\begin{abstract}
We report herein the characterization and binding properties of a microporous crystalline host formed by the self assembly of a bis-urea macrocycle $\mathbf{1}$. Bis-urea macrocycle $\mathbf{1}$ has been designed to crystallize into stacked hollow columns. The self-assembly process is guided primarily by hydrogen bonding and aromatic stacking interactions that yield crystals of filled host $\mathbf{1} \cdot$ acetic acid $(\mathrm{AcOH})$. The $\mathrm{AcOH}$ guests are bound in the cylindrical cavities of the crystal. The guest $\mathrm{AcOH}$ can be removed by heating to form a stable crystalline apohost $\mathbf{1}$. Apohost $\mathbf{1}$ displays a type $\mathrm{I}$ gas adsorption isotherm with $\mathrm{CO}_{2}$ that is consistent with an open framework microporous material. Apohost $\mathbf{1}$ binds a range of small molecule guests with specific stoichiometry. The formation of these inclusion complexes does not destroy the crystal framework and therefore apohost $\mathbf{1}$ can be reused, much like a zeolite. We investigated the structure of apohost $\mathbf{1}$ and its inclusion complexes by powder X-ray diffraction. The ability of guests to bind and their stoichiometry could be rationalized on the basis of the size, shape, and polarity of the guest molecules. Finally, the shape selectivity of these self-assembled porous materials was demonstrated in competition studies in which apohost $\mathbf{1}$ preferentially bound $p$-xylene from a mixture of xylene isomers.
\end{abstract}

\section{Introduction}

There has been great interest in identifying new porous materials that can selectively bind guest molecules. ${ }^{1}$ An important goal is the ability to design the size and selectivity of the cavities in these new porous materials, as they could be tailored for specific applications. Both metal coordination and hydrogen bonding interactions have been used to direct the self-assembly of homogeneous porous materials, with metal coordination generally yielding more robust frameworks. ${ }^{2}$ In contrast, porous materials assembled by hydrogen bonds usually have lower stability and collapse when the guests are removed. Although, in some cases, guests have

* Author to whom correspondence should be addressed. E-mail: shimizul@ mail.chem.sc.edu.

$\dagger$ University of South Carolina.

¥ University of North Florida.

(1) (a) Kesanli, B.; Cui, Y.; Smith, M. R.; Bittner, E. W.; Bockrath, B. C.; Lin, W. Angew. Chem., Int. Ed. 2005, 44, 72. (b) Cui, Y.; Lee, S. J.; Lin, W. J. Am. Chem. Soc. 2003, 125, 6014. (c) Dybtsev, D. N.; Chun, H.; Kim. K. Angew. Chem., Int. Ed. 2004, 43, 5033. (d) Wu, C. D.; Lin, W. Angew. Chem., Int. Ed. 2005, 44, 1958. (e) Wu, C. D.; Lin, W. Chem. Commun. 2005, 3673. (f) Eddaoudi, M.; Moler, D. B.; Li, H. L.; Chen, B. L.; Reineke, T. M.; O’Keeffe, M.; Yaghi, O. M. Acc. Chem. Res. 2001, 34, 319. (g) Muller, U.; Schubert, M.; Teich, F.; Puetter, H.; Schierle-Arndt, K.; Pastre, J. J. Mater. Chem. 2006, 16, 626. (h) Cui, Y.; Lee, S. J.; Lin, W. J. Am. Chem. Soc. 2004, 126, 32. (i) Pschirer, N. G.; Ciurtin, D. M.; Smith, M. D.; Bunz, U. H. F.; zur Loye, H.-C. Angew. Chem., Int. Ed. 2002, 41, 583. (j) Liu, Y.; Kravtsov, Ch. V.; Larsen, R.; Eddaoudi, M. Chem. Commun. 2006, 1488. (k) Li, C. J.; Hu, S.; Li, W.; Lam, C. K.; Zheng, Y. Z.; Tong, M. L. Eur. J. Inorg. Chem. 2006, 1931. (1) Wu, C. D.; Lin, W. Inorg. Chem. 2005, 44, 1178. (m) Lin, W. J. Solid State Chem. 2005, 178, 2486. (n) Horike, S.; Matsuda, R.; Tanaka, D.; Mizuno, M.; Endo, K.; Kitagawa, S. J. Am. Chem. Soc. 2006, 128, 4222. (o) Huang, X. C.; Lin, Y. Y.; Zhang, J. P.; Chen, X. M. Angew. Chem., Int. Ed. 2006, 45, 1557. (p) Kramer, M.; Schwarz, U.; Kaskel, S. J. Mater. Chem. 2006, 16, 2245. (q) Zou, R. Q.; Sakurai, H.; Xu, Q. Angew. Chem., Int. Ed. 2006, 45, 2542. been removed by exchange processes. ${ }^{3}$ Herein, we prepare and characterize a robust porous framework assembled from hydrogen-bonded units. This system is able to maintain its porous structure even upon removal of the included guest molecules. In addition, this porous material can reversibly bind other guest molecules.

The stability of this hydrogen-bonded system arises from the combination of multiple hydrogen-bonding interactions and from the stacking of rigid macrocycles. It has been shown that incorporation of multiple hydrogen-bond acceptors and donors into a single molecule greatly enhances the stability of assembled structures. ${ }^{4}$ In addition, many groups have used the self-assembly of macrocycles to create tubular structures. ${ }^{5}$ The columnar assembly of macrocycles forms stable porous channels that are defined by the aperture (internal size) of the macrocycle. The key design aspect of integrating these two strategies is to utilize the directional behavior of hydrogen bonds to ensure that the macrocycles are aligned to yield a porous channel (Figure 1). In contrast,

(2) (a) Steiner, T. Angew. Chem., Int. Ed. 2002, 41, 48. (b) James, S. L. Chem. Soc Rev. 2003, 32, 276. (c) Moulton, B.; Zaworotko, M. Chem. Rev. 2001, 101, 1629. (d) Prins, L. J.; Reinhoudt, D. N.; Timmerman, P. Angew. Chem., Int. Ed. 2001, 40, 2382.

(3) (a) Biradha, K.; Fujita, M. Angew. Chem., Int. Ed. 2002, 41, 3392. (b) Saied, O.; Maris, T.; Wuest, J. D. J. Am. Chem. Soc. 2003, 125 14956. (c) Laliberte, D.; Maris, T.; Wuest, J. D. J. Org. Chem. 2004, 69, 1776. (d) Laliberte, D.; Maris, T.; Sirois, A.; Wuest, J. D. Org. Lett. 2003, 5, 4787. (e) Venkataraman, D.; Gardner, G. B.; Lee, S.; Moore, J. S. J. Am. Chem. Soc. 1995, 117, 11600.

(4) a) Murray, T. J.; Zimmerman, S. C. J. Am. Chem. Soc. 1992, 114, 4010. (b) Sessler, J. L.; Wang, R. Angew. Chem., Int. Ed. 1998, 37 1726. (c) Pranata, J.; Wiertschke, S. G.; Jorgensen, W. L. J. Am. Chem. Soc. 1991, 113, 2810. (d) Jorgensen, W. L.; Pranata J. J. Am. Chem. Soc. 1990, 112, 2008 


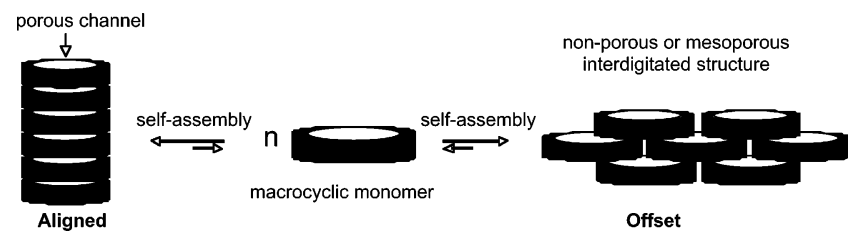

Figure 1. Possible modes of assembly into aligned or offset morphologies Note that only the aligned assembly yields a porous structure.

the formation of offset assemblies would yield nonporous materials.

Therefore, we have utilized a combination of hydrogen bonds and $\pi$-stacking interactions to align macrocycles into columnar assemblies (Scheme 1). ${ }^{6}$ We have previously described the modular synthesis of bis-urea macrocycle $\mathbf{1}$ from rigid spacers and protected urea groups and its self assembly to form a porous organic structure containing regular tubular channels. ${ }^{6}$ Macrocycle 1 was designed to contain urea groups, which are known to form strong directional hydrogen-bonding interactions. ${ }^{7}$ The rigid phenyl ether spacers of 1 preorganize the urea functionalities perpendicular to the plane of the macrocycle, an arrangement that is suited for the head-to-tail urea self-assembly and commensurate stacking of the macrocycles to form hollow cylinders. Aryl stacking interactions of the phenyl ethers provide additional stabilization of the assembly, and this rigid aryl framework of macrocycle $\mathbf{1}$ maintains an open cavity even in the absence of a guest. The variation in the size and shape of the rigid spacers could lead to "tunable" channels with dimensions tailored for specific applications.

The single-crystal X-ray structure confirmed that macrocycle 1 assembles in $\mathrm{AcOH}$ as designed to yield filled host $\mathbf{1} \cdot \mathrm{AcOH}$, which displays a tubular morphology with threecentered urea-urea hydrogen bonds extending along both sides of the structure (Figure 2). The channels formed by the assembly were filled with well-ordered acetic acid (AcOH) dimers. ${ }^{6}$ We observed that the $\mathrm{AcOH}$ could be removed from the channels, forming an empty crystalline material, apohost $1 .^{8}$ Apohost 1 was able to reabsorb $\mathrm{AcOH}$ from the vapor phase to reform the original filled host $\mathbf{1} \cdot$ AcOH. Furthermore, apohost $\mathbf{1}$ could be reused, much like a zeolite, and showed reversible absorption and desorption

(5) For reviews see: (a) Holman, K. T.; Pivovar, A. M.; Swift, J. A.; Ward, M. D. Acc. Chem. Res. 2001, 34, 107. (b) Braga, D.; Grepioni, F. Acc. Chem. Res. 2000, 33, 601. (c) Braga, D.; Grepioni, F.; Coord. Chem. Rev. 1999, 183, 19. (d) Nangia, A.; Desiraju, G. R. In Design of Organic Solids; Weber, E., Ed.; Springer: Berlin, 1998; Vol. 198, p 57. (e) Melendez, R. E.; Hamilton, A. D. In Design of Organic Solids; Weber, E., Ed; Springer: Berlin, 1998; Vol. 198, p 97. (f) Bong, D. T.; Clark, T. D.; Granja, J. R.; Ghadiri, M. R. Angew. Chem., Int. Ed. 2001, 40, 988. (g) Zhang, J.; Moore, J. S. J. Am. Chem. Soc. 1992, 114, 9701. (h) Moore, J. S. Acc. Chem. Res. 1997, 30, 402. (i) Kiang, Y. H.; Gardner, G. B.; Lee, S.; Xu, Z. T.; Lobkovsky, E. B. J. Am. Chem. Soc. 1999, 121, 8204.

(6) Shimizu, L. S.; Hughes, A. D.; Smith, M. D.; Davis, M. J.; Zhang, P.; zur Loye, H.-C.; Shimizu, K. D. J. Am. Chem. Soc. 2003, 125, 14972.

(7) (a) Etter, M. C.; Urbanczyk-Lipkowska, Z.; Zia-Ebrahimi, M.; Panunto, T. W. J. Am. Chem. Soc. 1990, 112, 8415. (b) Dannecker, W.; Kopf, J.; Rust, H. Cryst. Struct. Commun. 1979, 8, 429. (c) Carr, A. J.; Melendez, R.; Geib, S. J.; Hamilton, A. D. Tetrahedron Lett. 1998 , 39, 7447. (d) van Esch, J.; De Feyter, S.; Kellog, R. M.; De Schryver, F.; Feringa, B. L. Chem.-Eur. J. 1997, 3, 1238.

(8) An apohost is defined as the state of the host component from the crystallized host $\mathbf{1} \cdot \mathrm{AcOH}$ after the removal of the guest. of several guests, including $\mathrm{AcOH}$, ethyl acetate, DMSO, and THF by TGA. ${ }^{9}$

In this paper, we characterize the structure of apohost $\mathbf{1}$ and demonstrate that it maintains its porous open framework structure even in the absence of a guest, establishing that guest binding is not simply surface sorption. The size and binding selectivity of the channel of apohost 1 was examined. The structure of apohost $\mathbf{1}$ was probed by powder X-ray diffraction, and the porosity of apohost $\mathbf{1}$ was characterized by gas adsorption studies with carbon dioxide. The structural homogeneity and well-defined nature of the columnar cavity of apohost $\mathbf{1}$ allows small guests molecules to be bound with precise stoichiometry, and the confined channel can differentiate guests molecules based on shape. In addition, the structures of new inclusion complexes, host $\mathbf{1} \cdot$ guest have been examined by powder X-ray diffraction, ${ }^{1} \mathrm{H} \mathrm{NMR}$, and TGA.

\section{Experimental Section}

Materials. All the chemicals were purchased from Aldrich and used without further purification.

Synthesis of Bis-Urea Macrocycle 1. The previously described synthesis of macrocycle $\mathbf{1}$ was repeated and scaled to yield gram quantities. ${ }^{6}$ Monomer $\mathbf{1}$ was precipitated from water and isolated as an amorphous form.

Preparation of Filled Host 1 $\mathbf{A c O H}$. Precipitate 1 was dissolved in acetic acid $(100 \mathrm{mg} / 50 \mathrm{~mL})$ by heating $\left(120^{\circ} \mathrm{C}\right)$; it was then hot filtered and slowly cooled to room temperature. Clear colorless microcrystalline needles formed in 3-5 days and were collected on a sintered glass funnel. The crystals were too thin for singlecrystal X-ray analysis but showed powder diffraction patterns consistent with the previously reported X-ray structure. ${ }^{6}$

Preparation of Host $\mathbf{1}$. The filled host $\mathbf{1} \cdot \mathrm{AcOH}$ crystals were evacuated by heating at $120{ }^{\circ} \mathrm{C}$ for $2 \mathrm{~h}$ to form apohost 1 . The loss of the AcOH could be followed by TGA. The clear microcrystals of apohost 1 were cooled under an inert atmosphere $\left(\mathrm{He}\right.$ or $\mathrm{N}_{2}$ ).

Scanning Electron Microscopy (SEM) studies. Solutions containing filled host $\mathbf{1} \cdot \mathrm{AcOH}$ crystals in $\mathrm{AcOH}$ were loaded dropwise on a silicon sheet using a micropipet and allowed to airdry. The SEM image was recorded on an XL30 instrument in the ESEM mode with a 0.9 Torr vacuum (Figure 3). A second sample with apohost 1 was prepared similarly; however, the $\mathrm{AcOH}$ guest was removed from host $\mathbf{1} \cdot \mathrm{AcOH}$ by heating in an oven at $120^{\circ} \mathrm{C}$ for $2 \mathrm{~h}$ before the crystals were examined by SEM.

Absorption Studies. Crystalline apohost 1 was exposed to solvent vapor in a sealed chamber, and guest absorption followed for between 1 and 7 days until the system reached an equilibrium. The uptake of guest by apohost $\mathbf{1}$ to form host $\mathbf{1} \cdot$ guest was monitored by heating and measuring the change in weight by TGA and was verified independently by ${ }^{1} \mathrm{H}$ NMR.

Thermogravimetric Analysis (TGA) Studies. Guest desorption studies were carried out on 5-10 mg of apohost 1 after equilibration with each guest in the vapor chamber. TA Instruments SDT-2960 simultaneous DTA-TGA was used at a heating rate of $4{ }^{\circ} \mathrm{C} / \mathrm{min}$ from 25 to $140{ }^{\circ} \mathrm{C}$ under helium. Upon completion each sample was recollected for the next absorption-desorption cycle.

Powder X-ray Diffraction (PXRD) Studies. Samples of host 1.guest and apohost $\mathbf{1}$ were ground to a powder and examined by PXRD. X-ray powder diffraction data were collected on a Rigaku

(9) Shimizu, L. S.; Smith, M. D.; Hughes, A. D.; Samuel, S.; CiurtinSmith, D. Supramol. Chem. 2005, 17, 27. 

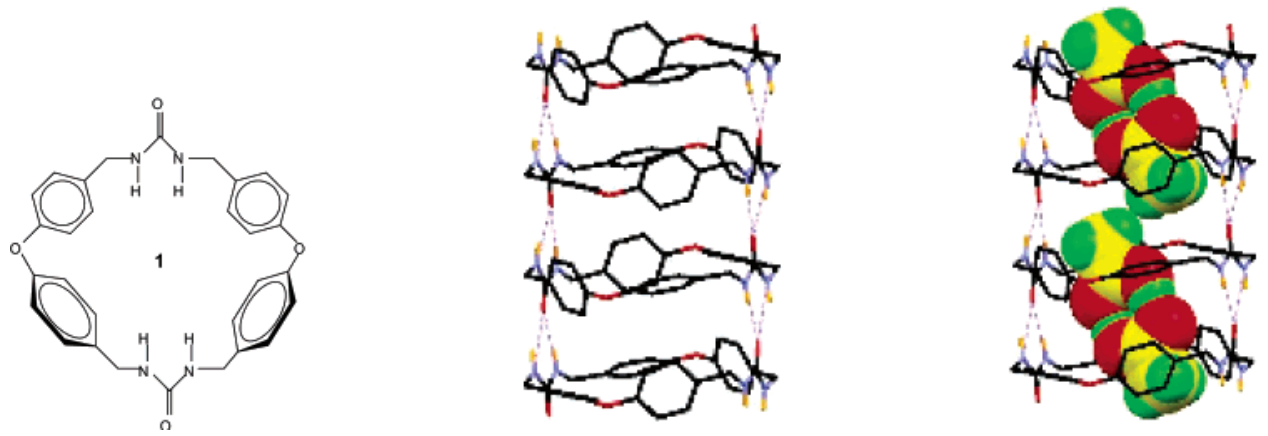

Figure 2. Bis-urea macrocycle 1: monomer (left); views from the single-crystal X-ray structure of filled host 1•AcOH showing columnar assembly (middle, guest omitted) and the well-ordered acetic acid guests (right). Hydrogen atoms were removed for clarity.

Scheme 1. Schematic View of Self Assembly and Reversible Absorption of Guests

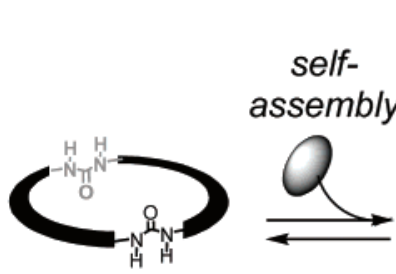

macrocycle 1 guest

desorption

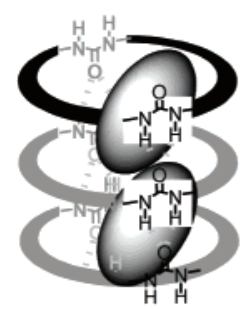

filled host $1 \bullet A c O H$

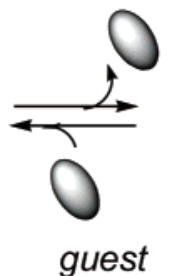

absorption

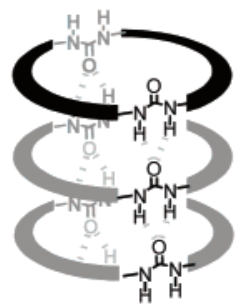

apohost 1 guest absorption

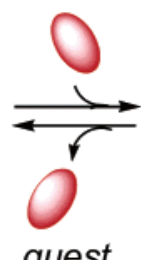

guest

desorption

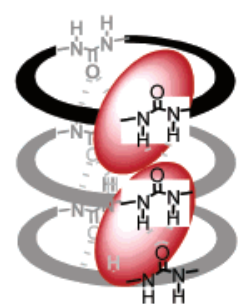

filled host $1 \cdot$ guest
DMAX-2100 powder X-ray diffractometer using $\mathrm{CuK} \alpha$ radiation. Data were collected at increments of $0.05^{\circ}$ and an exposure time of $5 \mathrm{~s} / \mathrm{step}$ in the angular range $2-20^{\circ} 2 \theta$ at ambient temperature.

Quantification of Guest Stoichiometry by ${ }^{\mathbf{1}} \mathbf{H}$ NMR. The crystalline apohost $\mathbf{1}(2 \mathrm{mg})$ was exposed to guest vapor in a sealed chamber for 1-7 days. The crystals were transferred directly into an NMR tube and dissolved in $1 \mathrm{~mL}$ of $\mathrm{d}_{6}$-DMSO solvent. The NMR tube was sonicated and gently heated until all the material was dissolved. The NMR spectra were recorded by a $300 \mathrm{MHz}$ Mercury Varian NMR spectrometer. Macrocycle:guest ratios were calculated from proton integration.

Solid-State NMR Studies. ${ }^{13} \mathrm{C}(125.79 \mathrm{MHz})$ solid-state NMR studies were acquired on unground apohost $\mathbf{1}$ and unground host 1·AcOH using a Varian Inova $500 \mathrm{MHz}$ spectrometer equipped with a double-resonance Doty Scientific XC $4 \mathrm{~mm}$ magic angle spinning (MAS) probe. Tangential ramped cross-polarization was performed with the vendor's supplied pulse sequence. A $1 \mathrm{~ms}$ contact time was used for all spectra with the exception of the crosspolarization build-up experiment. TPPM modulated dipolar decoupling with a $50 \mathrm{kHz}$ field strength was applied during data acquisition (40 ms). A $1 \mathrm{~s}$ equilibration delay was used between each transient. A spinning speed of $8 \mathrm{kHz}$ and TOSS sideband suppression were used for all measurements. The cross-polarization build-up experiment was performed at contact times of $0.2-1.6$
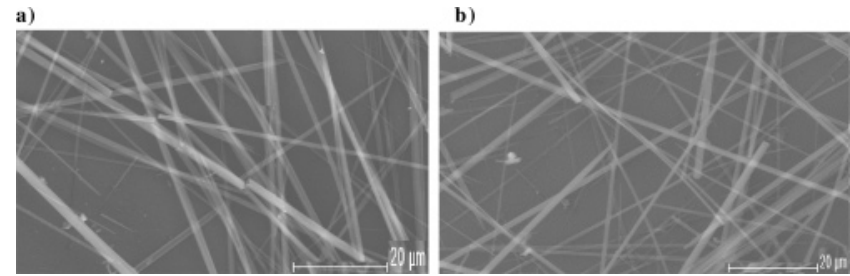

Figure 3. (a) SEM image of filled host $\mathbf{1} \cdot \mathrm{AcOH}(\mathrm{bar}=20 \mu \mathrm{m})$. (b) SEM image of apohost 1 (bar $=20 \mu \mathrm{m})$. ms. Values after these showed a gradual loss of intensity. True $\mathrm{T} 1 \rho$ for both ${ }^{1} \mathrm{H}$ and ${ }^{13} \mathrm{C}$ could not be measured because of safety limitations in the RF pulse duration ( $8 \mathrm{~ms}$ ).

Micropore Analysis. $\mathrm{CO}_{2}$ gas adsorption analyses were performed by Quantachrome Instruments, 1900 Corporate drive, Boynton Beach, FL 33426. Freshly recrystallized host $\mathbf{1} \cdot \mathrm{AcOH}$ (100 $\mathrm{mg}$ ) was analyzed by TGA to confirm its $\mathrm{AcOH}$ binding capacity and porous structure. The guest was removed by heating and apohost 1 was then sent to Quantachrome for gas absorption analysis using a Quantachrome Autosorb 1 instrument. $\mathrm{CO}_{2}$ gas $\left(P_{0}=\right.$ 26115 Torr for $\mathrm{CO}_{2}$ at $273 \mathrm{~K}$ and $P_{0}=1414$ Torr at $195 \mathrm{~K}$ ) was used as adsorbate and the isotherm was generated at $0{ }^{\circ} \mathrm{C}(273 \mathrm{~K})$ and $-78{ }^{\circ} \mathrm{C}(195 \mathrm{~K})$. An isotherm at $0{ }^{\circ} \mathrm{C}$ with 40 points in adsorption and 20 in desorption was measured in a pressure range of $0.05-0.995$. The actual relative pressure was $0.0003-0.03$ after correcting for the $P_{0}$ value at $273 \mathrm{~K}$. A second isotherm was measured at $-78{ }^{\circ} \mathrm{C}$ with 23 points in adsorption in a pressure range of $0.05-0.995$ with a $P_{0}$-corrected pressure of $0.05-0.5$. The volume pressure data thus obtained were reduced using Autosorb software for surface area, total pore volume, and pore size distribution calculations.

\section{Results and Discussion}

The structure of filled host $\mathbf{1} \cdot \mathrm{AcOH}$ contains ordered $\mathrm{AcOH}$ guests in a 1:1 ratio (macrocycle $\mathbf{1}: \mathrm{AcOH}$ ) that fill the columnar cavities formed by the stacked macrocycles. ${ }^{6}$ The guest $\mathrm{AcOH}$ could be quantitatively removed from the structure by heating to form apohost $\mathbf{1}$. The $\mathrm{AcOH}$ could also be reintroduced into this host returning to the initial host 1·AcOH (Scheme 1). ${ }^{6}$ The host could also absorb other small molecule guests to form new inclusion complexes. These binding properties appear to be directly related to the assembled structure of host $\mathbf{1} \cdot \mathrm{AcOH}$, as amorphous $\mathbf{1}$ col- 


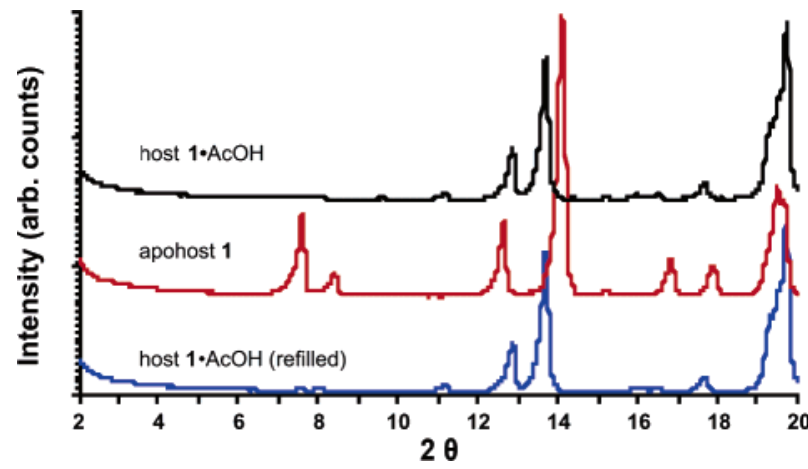

Figure 4. PXRD patterns for filled host $\mathbf{1} \cdot \mathrm{AcOH}$ (top). Apohost $\mathbf{1}$ after $\mathrm{AcOH}$ removal by heating (middle). Refilled host $\mathbf{1} \cdot \mathrm{AcOH}$ after $\mathrm{AcOH}$ reinsertion by vapor treatment (bottom).

lected from precipitation from $\mathrm{H}_{2} \mathrm{O}$ shows no $\mathrm{AcOH}$ binding. The acetic acid solvent appears to play a role in assembly of macrocycle $\mathbf{1}$ into this columnar framework, and crystals formed from AcOH:propanoic acid showed a different assembly pattern. This paper explores the structure and binding properties of apohost $\mathbf{1}$ and the properties of the new inclusion complexes (host 1•guest) via SEM, PXRD, and gas adsorption studies.

Host $\mathbf{1} \cdot \mathrm{AcOH}$ typically forms thin needlelike crystals from AcOH. SEM measurements of the crystals estimated their average size as $\sim 250 \mu \mathrm{M} \times 3 \mu \mathrm{M}$ (Figure $3 \mathrm{a}$ ). ${ }^{10} \mathrm{The} \mathrm{AcOH}$ guests were removed from the microcrystals of host $\mathbf{1} \cdot \mathrm{AcOH}$ by heating. The apohost $\mathbf{1}$ crystals remained clear and colorless and showed no change in morphology or average size. ${ }^{11}$ SEM images showed no changes between the filled host $\mathbf{1}$. $\mathrm{AcOH}$ crystals and the apohost 1 (Figure 3b). The apohost 1 crystals are robust and display no phase changes up to $300{ }^{\circ} \mathrm{C}$ by differential scanning calorimetry.

We examined the structure of filled host $\mathbf{1} \cdot \mathrm{AcOH}$ and apohost $\mathbf{1}$ by PXRD. ${ }^{6} \mathrm{Host} \mathbf{1} \cdot \mathrm{AcOH}$ was ground to a powder and examined by PXRD (Figure 4, top). The guest was removed from the bulk powder by heating to $100{ }^{\circ} \mathrm{C}$ for $3 \mathrm{~h}$. The absence of guest was confirmed by ${ }^{1} \mathrm{H}$ NMR. The PXRD pattern of apohost $\mathbf{1}$ shows a different but welldefined structure (Figure 4, middle). Upon treatment with $\mathrm{AcOH}$ vapor for $24 \mathrm{~h}$, this empty powder reabsorbed $\mathrm{AcOH}$ in a 1:1 ratio and exhibited a PXRD pattern with peak positions and intensities nearly identical to the original bound structure, filled host $\mathbf{1} \cdot \mathrm{AcOH}$ (Figure 4 , bottom). ${ }^{12}$

These studies demonstrated that the PXRD patterns in the presence and absence of the guest are an effective means of monitoring structural changes that may be occurring upon guest desorption. Using the previously reported single-crystal X-ray of host $\mathbf{1} \cdot \mathrm{AcOH}(a=9.32 \AA, b=21.88 \AA, c=13.95$ $\AA$ А, $\beta=100.85^{\circ}$ ), we calculated PXRD patterns for host $\mathbf{1}$. AcOH using POUDRIX (Figure 6). ${ }^{13}$ The simulated PXRD

(10) The average size of the crystals including a standard deviation was $\sim(250 \pm 90) \mu \mathrm{M} \times(3 \pm 1) \mu \mathrm{M}$. The smallest dimension of the crystal could not be accurately measured from the SEM image.

(11) The average size of unground apohost $\mathbf{1}$ crystals was estimated by SEM as $\sim(260 \pm 100) \mu \mathrm{M} \times(3 \pm 2) \mu \mathrm{M}$.

(12) This experiment was also reported in our earlier J. Am. Chem. Soc. communication, ref 6 . There appears to have been an impurity present in the earlier study in both the apohost $\mathbf{1}$ and filled host $\mathbf{1} \cdot \mathrm{AcOH}$ that was not observed in these experiments.

(13) Altermatt, U. D.; Brown, I. D. Acta Crystallogr., Sect. A 1987, 43, 125 . pattern closely matches the observed pattern, supporting the hypothesis that the bulk powder retains a structure similar to the single crystal (Figure 5a). For apohost $\mathbf{1}$, a simulated diffraction pattern was calculated using POUDRIX after removing the atomic coordinates associated with the acetic acid from the host $\mathbf{1} \cdot \mathrm{AcOH} \mathrm{X}$-ray structure while retaining the same lattice parameters. Of course, there will be some atomic rearrangement upon removal of the acetic acid; however, we treated the host as a rigid unit as a first approximation. The large degree of structural complexity and number of parameters prevent a complete structural analysis of the polycrystalline sample by structure refinement techniques. The features of the simulated diffraction pattern for apohost 1 shows reasonably good agreement with the experimental pattern, especially the large increase in intensity of the low angle peaks. The simulated pattern correctly predicts the large increase in intensity of the 011 and 020 peaks observed near $2 \theta=7.6$ and $8.4^{\circ}$ (Figure $5 \mathrm{~b}$ ). These results suggest that the long-range order of the host is retained in the absence of the guest.

Assuming the space group remains unchanged, we performed a least-squares refinement of the lattice parameters of apohost 1. Comparison of the refined unit cell of apohost $\mathbf{1}$ to the filled host $\mathbf{1} \cdot \mathrm{AcOH}$ (Figure 6) indicates that the unitcell parameter $a$, which lies along the long axis of the tubes, undergoes minimal change from 9.32 to $9.29 \AA$ (Table 1 ). Changes are also observed in cell parameter $c$, which lengthens slightly from 13.96 to $14.39 \AA$. Removal of the $\mathrm{AcOH}$ guest most significantly affects unit-cell parameter $b$, which shortens slightly from 21.88 to $21.05 \AA$. In the host, the decrease in the $b$ lattice parameter is evident in the shift of the experimentally observed 030 peak at $2 \theta=14.1^{\circ}$ compared to a position of $13.9^{\circ}$ when the lattice parameters are fixed at the values of the filled host $\mathbf{1} \cdot \mathrm{AcOH}$. We did not simulate the diffraction pattern with the refined unit cell of apohost $\mathbf{1}$, because the atomic positions are not rigorously known in the refined unit cell of apohost 1; therefore, retaining the atomic positions with the refined cell would generate some nonphysical bond distances. Clearly, additional studies are needed to accurately determine the complete crystal structure of apohost $\mathbf{1}$. The agreement between the simulated and experimental diffraction patterns suggest that although there are certainly some slight structural differences between apohost $\mathbf{1}$ and host $\mathbf{1} \cdot \mathrm{AcOH}$, the long-range structural order appears to be retained. We are currently attempting to grow single crystals to better elucidate the structural changes between host $\mathbf{1} \cdot \mathrm{AcOH}$ and apohost $\mathbf{1}$.

Gas Adsorption Studies. From the PXRD studies, we conclude that the host has a long-range order similar to that of filled host $\mathbf{1} \cdot \mathrm{AcOH}$; however, we have not established that apohost 1 retains a stable open channel as predicted. Noncovalent assemblies often collapse into more dense structures upon guest removal and do not maintain permanent voids. ${ }^{14}$ However, many such systems are flexible enough that they are able to re-adsorb guests, returning to the original

(14) (a) Bradshaw, D.; Claridge, J. B.; Cussen, E. J.; Prior, T. J.; Rosseinsky, M. J. Acc. Chem. Res. 2005, 38, 273. (b)Aoyama, Y. Top. Curr. Chem. 1998, 198, 131. 

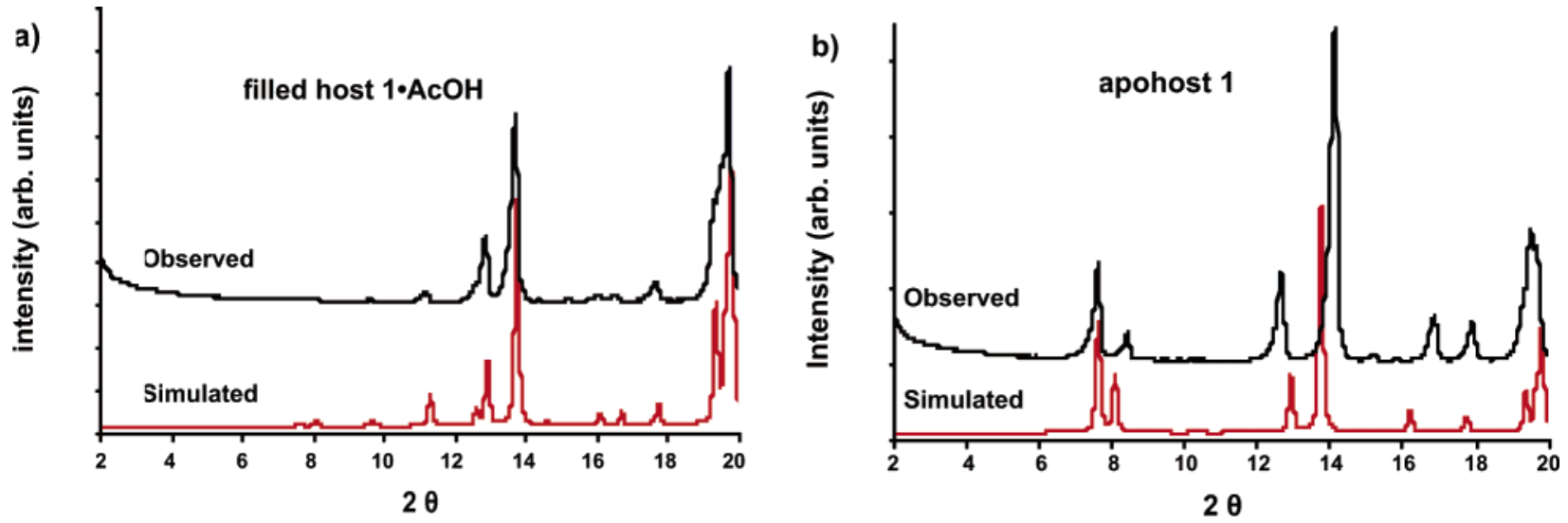

Figure 5. (a) Comparison of observed and simulated PXRD patterns of filled host $\mathbf{1} \cdot \mathrm{AcOH}$. (b) Comparison of observed and simulated PXRD patterns for apohost 1.

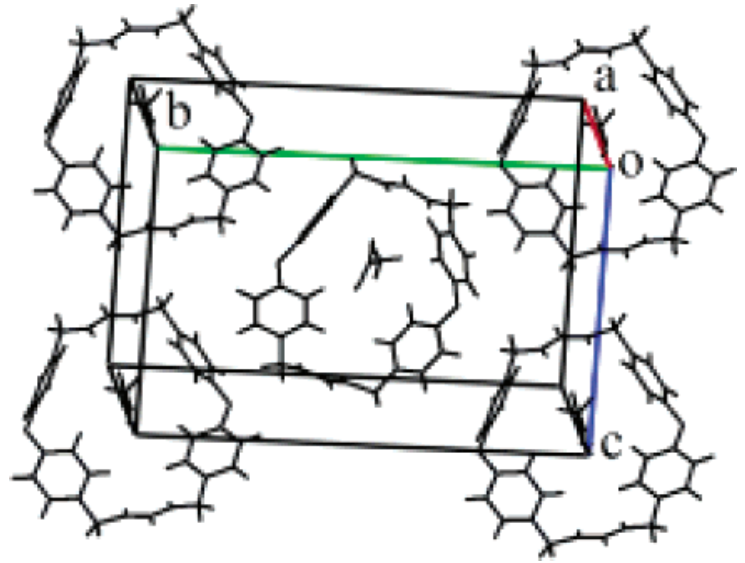

Figure 6. Monoclinic host $\mathbf{1} \cdot \mathrm{AcOH}$, space group $P 2_{1} / c$ with unit cell volume $=2796.8(2) \AA^{3}$. Cell parameter $a$ lies along the axis of the columns.

Table 1. Comparison of Unit-Cell Parameters for Filled Host 1.AcOH and Apohost 1

\begin{tabular}{lcc}
\hline & $\begin{array}{c}\text { host } \mathbf{1} \cdot \text { AcOH } \\
\text { observed by X-ray }\end{array}$ & $\begin{array}{c}\text { apohost } \mathbf{1} \text { calcd } \\
\text { from PXRD pattern }\end{array}$ \\
\hline$a(\AA)$ & 9.3219 & 9.29 \\
$b(\AA)$ & 21.8875 & 21.051 \\
$c(\AA)$ & 13.9573 & 14.392 \\
$\beta($ deg $)$ & 100.85 & 103.41 \\
$V\left(\AA^{3}\right)$ & 2797 & 2741
\end{tabular}

host-guest structure. ${ }^{15}$ Gas sorption studies can provide evidence that a material maintains permanent voids, such as the "empty" channel structure proposed for apohost $\mathbf{1}$. These studies are typically carried out by gas adsorption, and porous materials are classified on the basis of their pore sizes as micro- (diameter $(d)<2 \mathrm{~nm})$, meso- $(2 \mathrm{~nm}<d<50 \mathrm{~nm}$ ), or macroporous materials $(d>50 \mathrm{~nm}) .{ }^{16}$ Typically, adsorption isotherms are grouped by type (I-VI), ${ }^{17}$ with a type I isotherm being indicative of microporous systems. ${ }^{18}$ The

(15) (a)Aoyama, A.; Endo, K.; Kobayashi, K.; Masuda, H. Supramol. Chem. 1995, 4, 229. (b) Endo, K.; Sawaki, T.; Koyangi, M.; Kobayashi, K.; Masuda, H.; Aoyama, Y. J. Am. Chem. Soc. 1995, 117, 8341. (c) Scott, J. L. J. Chem. Soc., Perkin Trans. 2 1995, 495. (d) Csoregh, I.; Hirano, S.; Toyota, S.; Bómbix, P.; Toda, F. CrystEngComm 2004, 6, 60. (e) Wen, M.; Munakata, M.; Suenaga, Y.; Kuroda-Sowa, T.; Maekawa, M. Inorg. Chim. Acta 2002, 8. (f) Carlson, S. J.; Lu, T.; Luck, R. L. Inorg. Chem. Commun. 2003, 6, 455. (g) Rahaman, A. N. M. M.; Bishop, R.; Craig, D. C.; Scudder, M. L. Eur. J. Org. Chem. 2003, 72. standardized adsorption experiment incrementally increases the partial pressure $(P)$ of the gas, usually $\mathrm{N}_{2}$, above a sample and records the amount of $\mathrm{N}_{2}$ adsorbed after an equilibrium is reached. ${ }^{19}$ Relative pressures $\left(P / P_{0}\right)$ are calculated, where $P_{0}$ is the saturation pressure of the gas at the experimental temperature. For high-surface-area materials at low temperature $(77 \mathrm{~K}), \mathrm{N}_{2}$ adsorption can take days and, in practice, it is more reliable to measure $\mathrm{CO}_{2}$ sorption at $273-298 \mathrm{~K}$, conditions that favor adsorption at low partial pressures. ${ }^{20}$ For example, the porosity of metal-organic frameworks with tubular channels have been measured by $\mathrm{CO}_{2}$ adsorption and show type I adsorption isotherms, ${ }^{1 \mathrm{a}, 21}$ displaying sharp uptake at $P / P_{0}<0.1 .^{22}$

The porosity of apohost 1 was confirmed by $\mathrm{CO}_{2}$ gas adsorption measurements. These measurements were performed by Quantachrome Instruments using a Quantachrom Autosorb 1. Apohost 1 was outgassed overnight at $120{ }^{\circ} \mathrm{C}$. The adsorption isotherms were measured at two different temperatures $\left(0\right.$ and $\left.-78{ }^{\circ} \mathrm{C}\right)$. The adsorption isotherm at $0{ }^{\circ} \mathrm{C}$ shows $\mathrm{CO}_{2}$ uptake at $P / P_{0}<0.03$, consistent with a microporous material (Figure 7a). Desorption at $0{ }^{\circ} \mathrm{C}$ showed no hysteresis, suggesting that the adsorption behavior was due to microporosity. The adsorption isotherm could not be followed to saturation at $0{ }^{\circ} \mathrm{C}$ because of the higher vapor pressure of $\mathrm{CO}_{2}$. Therefore, the $\mathrm{CO}_{2}$ adsorption isotherm was

(16) (a) Sing, K. S. W.; Everett, D. H.; Haul, R. A.; Moscou, L.; Pierotti, J.; Rouquerol, J.; Siemieniewska, T. Pure Appl. Chem. 1985, 57, 603. (b) Soler-Illia, G. J. de A.; Sanchez, C.; Lebeau, B.; Patarin, J. Chem. Rev. 2002, 102, 4093. (c) Boucher, E. A. J. Mater. Sci. 1976, 11, 1734. (d) Ravikovitch, P. I.; Neimark, A. V. Colloids Surf., A 2001, 187, 11. (e) Lee, J. Y.; Li, J.; Jagiello, J. J. Solid State Chem. 2005, $178,2527$.

(17) Sing, K. S. W.; Everett, D. H.; Haul, R. A. W.; Moscou, L.; Pierotti, R. A.; Rouquerol, J.; Siemieniewska, T. Pure Appl. Chem. 1985, 57, 603.

(18) a) Barton, T. J.; Bull, L. M.; Klemperer, W. G.; Loy, D. A.; McEnaney, B.; Misono, M.; Monson, P. A.; Pez, G.; Scherer, G. W.; Vartuli, J. C.; Yaghi, O. M. Chem. Mater. 1999, 11, 2633. (b) Groen, J. C.; Peffer, L.; Perez-Ramirez, J. A. A. Microporous Mesoporous Mater. 2003, 60, 1. (c) Sing, K. S. W. Colloids Surf. 1989, 38, 113. (d) Lu, R.; Tangbo, H.; Wang, Q.; Xiang, S. J. Nat. Gas Chem. 2003, 12, 56.

(19) American Society of Testing Materials, Committee on Catalysts-D32, ASTM Report D3663-84; ASTM: West Conshohocken, PA, 1988

(20) Gregg, S. J.; Sing, K. S. W. Adsorption, Surface Area and Porosity, 2nd ed.; Academic: London, 1982.

(21) Dybtsev, D. N.; Chun, H.; Yoon, S. H.; Kim, D.; Kim, K. J. Am Chem. Soc. 2004, 126, 32.

(22) Côté, A. P.; Benin, A. I.; Ockwig, N. W.; O’Keeffe, M.; Matzger, A. J.; Yaghi, O. M. Science, 2005, 310, 1166. 

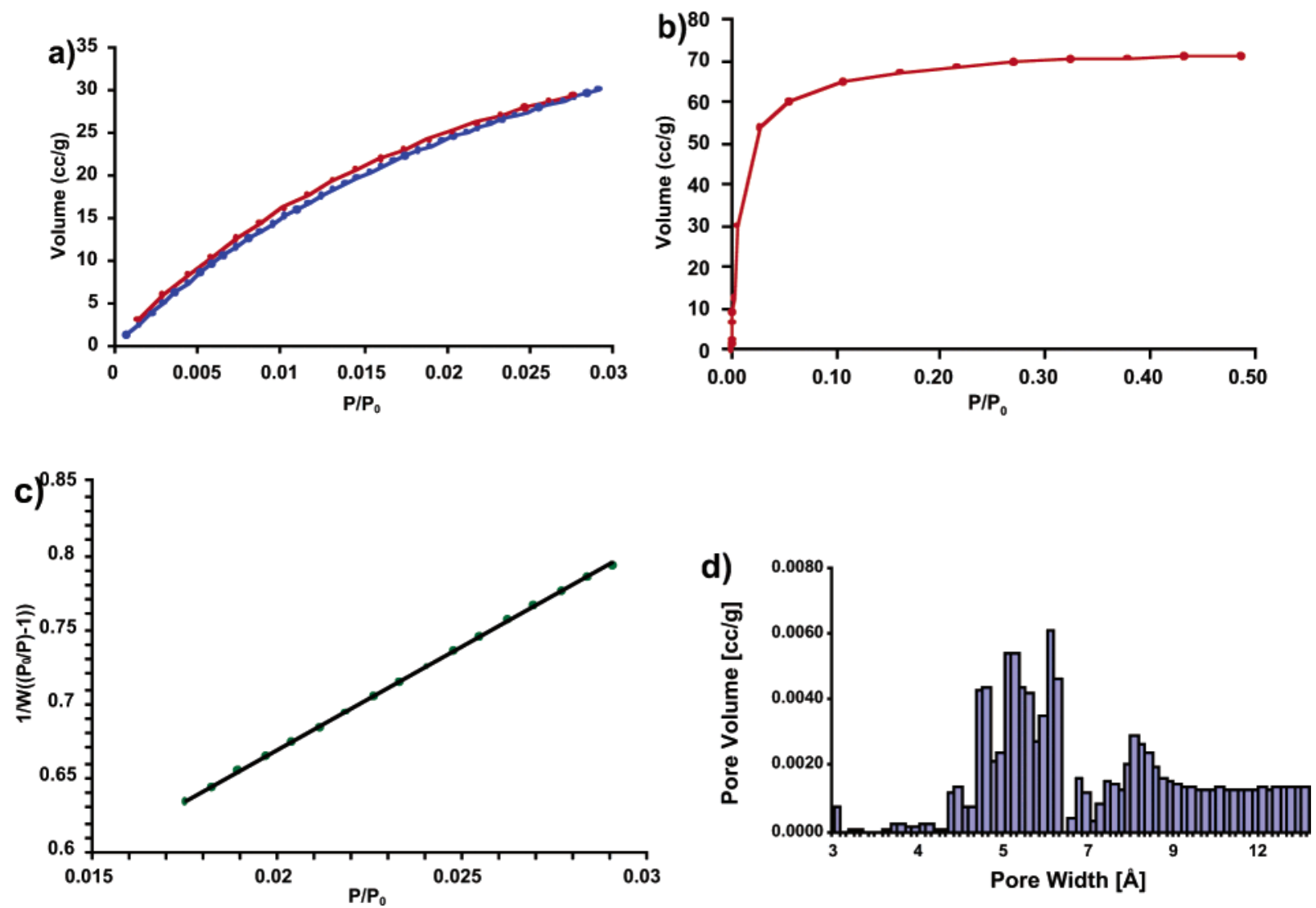

Figure 7. (a) Carbon dioxide adsorption isotherms at $0{ }^{\circ} \mathrm{C}$ for apohost 1. (b) Carbon dioxide adsorption isotherms at $-78{ }^{\circ} \mathrm{C}$ for apohost 1 . (c) Linearized BET plot of the $\mathrm{CO}_{2}$ adsorption at $0{ }^{\circ} \mathrm{C}$. (d) Pore size distribution histogram calculated for the adsorption isotherm at $0{ }^{\circ} \mathrm{C}$.

remeasured at $-78{ }^{\circ} \mathrm{C}$ to $P / P_{0}=0.5$ and reached saturation (Figure $7 \mathrm{~b}$ ). The isotherm displayed a very sharp uptake at $P / P_{0}<0.05$, a feature of a type I isotherm indicative of a microporous material. The $\mathrm{CO}_{2}$ uptake at saturation was calculated to be $71.5 \mathrm{~cm}^{3} / \mathrm{g}$ at $P / P_{0}=0.5$ and $-78^{\circ} \mathrm{C}$. The Brunauer-Emmett-Teller (BET) method was applied to the isotherm at $P / P_{0}$ between 0.018 and 0.029 and gave an apparent surface area of $316 \mathrm{~m}^{2} / \mathrm{g}$ at $0{ }^{\circ} \mathrm{C}$ (Figure $7 \mathrm{c}$ ) and $341 \mathrm{~m}^{2} / \mathrm{g}$ at $-78{ }^{\circ} \mathrm{C}$ (not shown). ${ }^{23}$ Similar surface area measurements are typical for microporous zeolites; ${ }^{24}$ for example, zeolite CsZSM-5 shows a surface area of $310 \mathrm{~m}^{2} / \mathrm{g}$ at $0{ }^{\circ} \mathrm{C} .{ }^{25}$ The total pore volume was calculated as being $0.059 \mathrm{~cm}^{3} / \mathrm{g}$ at $0{ }^{\circ} \mathrm{C}$ for pores smaller than $6.5 \AA$ in diameter at $P / P_{0}=0.029 .26$

Monte Carlo simulations and nonlocal density functional theory (NLDFT) provide methods of analyzing pore size distributions of porous materials. ${ }^{27}$ Ravikovitch et al. have introduced the NLDFT model for pore size characterization on the basis of $\mathrm{CO}_{2}$ isotherms measured at $0{ }^{\circ} \mathrm{C}$ at subatmospheric pressures. ${ }^{28}$ The absorbance isotherm cal-

(23) Farauto, R. J.; Bartholomew, C. H. Fundamentals of Industrial Catalytic Processes; John Wiley and Sons: New York, 2003; p 124

(24) (a) Cundy, C. S. Chem. Rev. 2003, 103, 663. (b) Corma, A.; DiazCabanas, M. J. Microporous Mesoporous Mater. 2006, 89, 39.

(25) Yamazaki, T.; Katoh, M.; Ozawa, S.; Ogino, Y. Mol. Phys. 1993, 80 , 313.

(26) The density of $\mathrm{CO}_{2}$ at $-78{ }^{\circ} \mathrm{C}$ under gas adsorption conditions was not known; therefore, we did not calculate the total pore volume for this temperature.

(27) Ravikovitch, P. I.; Vishnyakov, A.; Russo, R.; Neimark, A. V. Langmuir 2000, 16, 2311. culated by Quantachrome Instruments using Autosorb software with NLDFT methods closely matched the experimental isotherm (relative fitting error $=0.030 \%$ ). ${ }^{29}$ These NLDFT methods were used to calculate the pore size distribution (Figure 7d). The distribution is broad from 5 to $12 \AA$ with a majority of pores displaying a pore width of 5-6 $\AA$ and some slightly larger pores around $\sim 8 \AA$.

The reported X-ray structure of filled host $\mathbf{1} \cdot \mathrm{AcOH}$ is helpful for understanding the origin of this pore distribution. ${ }^{6}$ The channel formed by the stacked macrocycles is not a perfect cylindrical structure, but has a wider opening $\sim 8 \AA$ above and below the plane of the macrocycle and a more narrow space in the plane because of the position of two phenyl groups that point inward (Figure 8). The van der Waals surfaces ${ }^{30}$ of the pore defining atoms from the carbonyl carbon (C16A) to the phenyl hydrogen (H8) is $4.8 \AA .^{31}$ Estimation of the cross-section at this point is $\sim 3.8 \times 4.8 \AA$. Calculations on host $\mathbf{1} \cdot \mathrm{AcOH}$ using PLATON also predict

(28) Ravikovitch, P. I.; Gusev, V. Yu.; Leon y Leon, C. A.; Neimark, A. V. In 23rd Biennial Conference on Carbon, Extended Abstracts; Penn State University: College Park, PA, 1997; Vol. 1, p 605.

(29) All calculations were performed by Quantachrome instruments. NLDFT methods show a good fit to the experimentally observed adsorption isotherm at $0{ }^{\circ} \mathrm{C}$; however, some error is associated with this isotherm having not reached saturation. Also, the calculations using the Autosorb 1.51 software assume slit pores as NLDFT methods for cylindrical pores are not yet available for $\mathrm{CO}_{2}$ at $\mathrm{O}{ }^{\circ} \mathrm{C}$.

(30) Bondi, A. J. Phys. Chem. 1964, 68, 441.

(31) The distances were calculated from the X-ray structure, CCDC reference number 228322, using the internuclear distances - the sum of van der Waals radii of the atoms involved. The van der Waals radii used to define the surfaces were $\mathrm{H}=1.20 \AA \mathrm{C}=1.70 \AA$. 

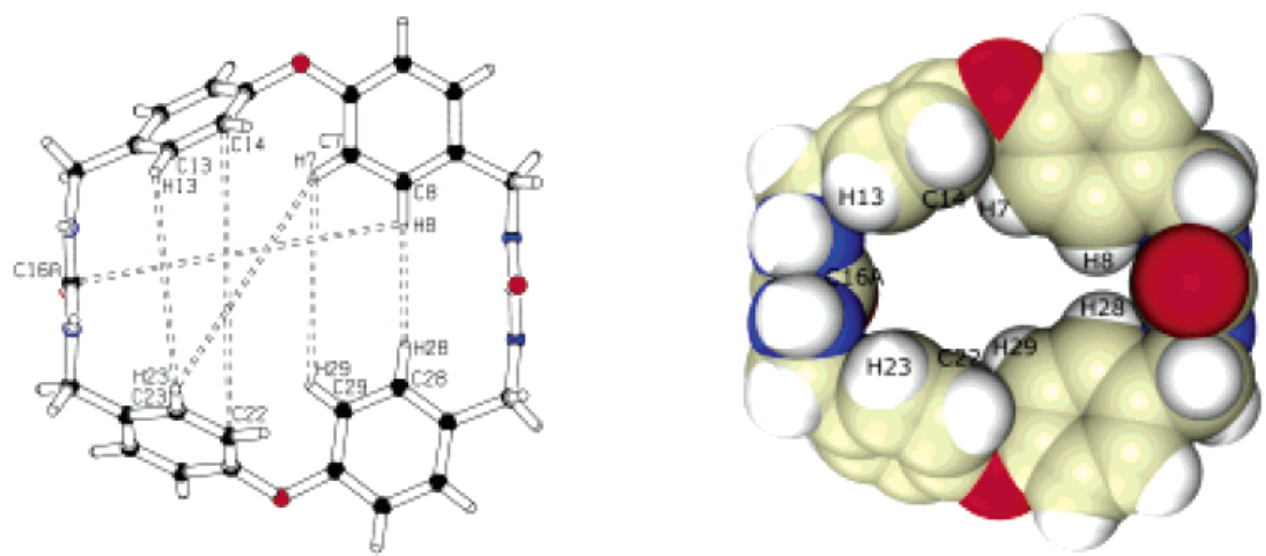

Figure 8. Views from the X-ray structure of filled host $\mathbf{1} \cdot \mathrm{AcOH}$ illustrate the narrow opening in the plane of the macrocycle. The distance between the van der Waals surfaces of the pore-defining atoms from the carbonyl carbon (C16A) to the phenyl hydrogen (H8) is $4.8 \AA$ and that between phenyl hydrogens (H7 to $\mathrm{H} 23$ ) is $3.8 \AA$.
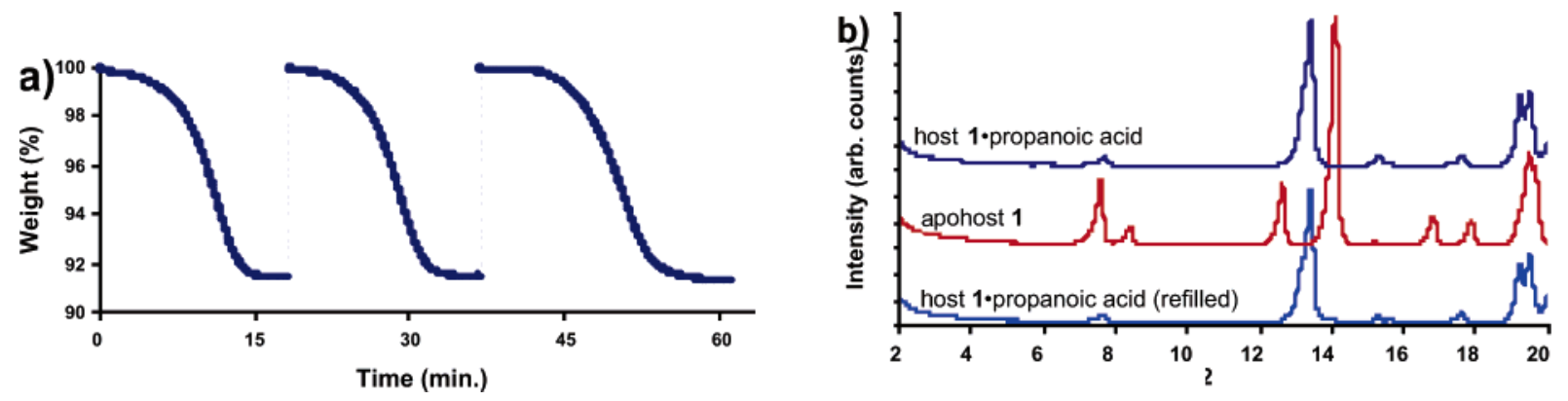

Figure 9. (a) Three successive cycles showing TGA desorption for assembled 1•propanoic acid followed by reloading of the propanoic acid guest. (b) PXRD patterns for host $\mathbf{1} \cdot$ propanoic acid (top), apohost $\mathbf{1}$ after propanoic acid removal (middle), and host $\mathbf{1} \cdot$ propanoic acid refilled (bottom).

the host should show porosity and contain guest-accessible void space. ${ }^{32}$ The void volume for host $\mathbf{1} \cdot \mathrm{AcOH}$ is estimated as being $13.7 \%$ of the unit-cell volume $\left(383 \AA^{3}\right.$ per $2797 \AA^{3}$ of unit-cell volume). In summary, apohost $\mathbf{1}$ appears to have a robust framework, to maintain open, accessible pores at both 0 and $-78{ }^{\circ} \mathrm{C}$, and shows $\mathrm{CO}_{2}$ gas adsorption consistent with a microporous material.

Reversible Absorption/Desorption of AcOH. If guests are really binding into a channel with a diameter of $\sim 6.5 \AA$, as indicated by the gas adsorption data, versus a multiple pore/surface absorption, then we would expect guests to bind with a specific stoichiometry that is not dependent on surface area. Also, we predict that such a defined tubular channel would have size and shape specificity. We therefore investigated the absorption of larger guests into apohost $\mathbf{1}$ and examined the limits of the stability of this system.

Host $\mathbf{1} \cdot \mathrm{AcOH}$ is formed by crystallization from $\mathrm{AcOH}$ (Figure 2) and contains guest $\mathrm{AcOH}$ dimers that could be removed and rebound. The binding stoichiometry of $\mathrm{AcOH}$ was determined by TGA to be $1: 1$, identical to that reported in the single-crystal structure. ${ }^{6}$ If binding were a surface phenomenon, then the binding ratio would increase with increasing surface area. Therefore, apohost 1 crystals were ground to a microcrystalline powder and equilibrated with $\mathrm{AcOH}$ vapor in a sealed chamber for $24-72 \mathrm{~h}$ to form filled host $\mathbf{1} \cdot \mathrm{AcOH}$. Both the ground apohost $\mathbf{1}$ and host $\mathbf{1} \cdot \mathrm{AcOH}$ were found by SEM to be $\sim 2 \mu \mathrm{M}$ powders.

Both ground and unground host $\mathbf{1} \cdot \mathrm{AcOH}$ showed reversible desorption of AcOH. The average weight loss for 71 absorption-desorption cycles from different batches/sizes of ground and unground crystals was $10.13 \pm 0.37 \%$, which corresponds to $\sim 1: 1$ binding of $\mathrm{AcOH}$ (calculated weight loss $10.56 \%$ ). The binding ratio does not appear to be dependent on crystal size, which varied from $\sim 250 \times 3 \mu \mathrm{M}$ for the unground crystals to a $\sim 2 \mu \mathrm{M}$ ground crystals. These observations support the hypothesis that the guest is bound inside the structure and not absorbed on the surface.

Reversible Binding of Propanoic Acid. Next, we wanted to investigate if apohost $\mathbf{1}$ could bind larger carboxylic acids. We first tested propanoic acid, which has a slightly larger volume than $\mathrm{AcOH}$ (72 vs $55 \AA^{3}$ as calculated by Macromodel). ${ }^{33}$ Both ground and unground apohost 1 were exposed to propanoic acid vapor in a sealed chamber for $24-72 \mathrm{~h}$, forming host 1-propanoic acid. No difference in binding was observed at the longer exposure times, suggesting that the system reached an equilibrium by $24 \mathrm{~h}$. The presence of guest in the host was observed by TGA measurements and verified independently by ${ }^{1} \mathrm{H}$ NMR. Integration of the ${ }^{1} \mathrm{H}$ NMR spectra of the unground host $\mathbf{1} \cdot$ propanoic acid dissolved in $\mathrm{d}_{6}$-DMSO gave a calculated binding stoichiometry of 3.12:1 (macrocycle:propanoic acid). A weight loss of $8.56 \%$ was measured by TGA for unground host $\mathbf{1}$-propanoic acid, occurring between 40 and $120^{\circ} \mathrm{C}$ and corresponding to loss of the propanoic acid guest (Figure 9a, cycle 1). Two additional absorption-desorption cycles with the same crystals gave nearly identical weight loss curves. The data show that apohost $\mathbf{1}$ is able to bind the larger propanoic acid and that

(32) (a) Spek, A.L. Platon; Utrecht University: Utrecht, The Netherlands, 1980-2006. (b) Spek, A. L. J. Appl. Crystallogr. 2003, 36, 7.

(33) Modeling was performed using Macromodel 5.5; Columbia University: New York, 1996. 


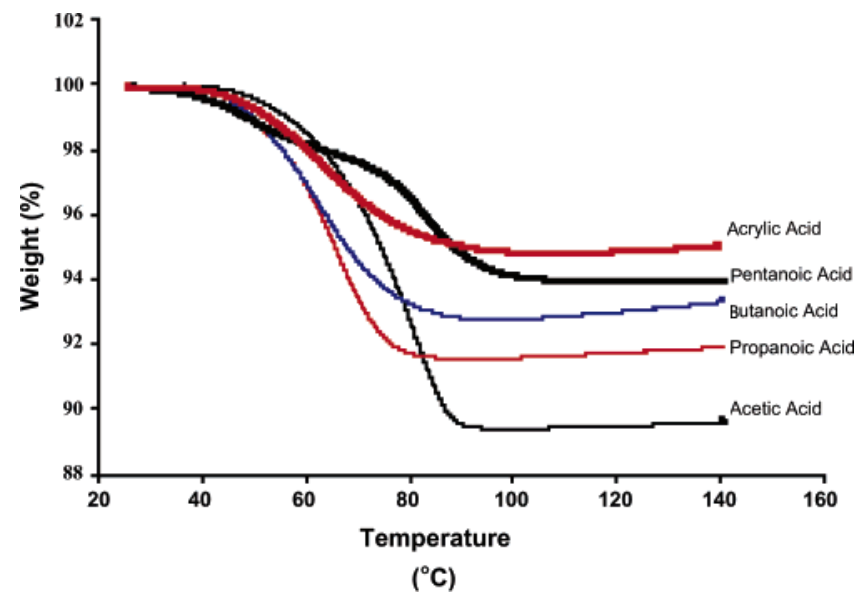

Figure 10. TGA desorption curves for a series of new inclusion complexes, host $\mathbf{1} \cdot$ carboxylic acid. All the carboxylic acid that displayed single-step TGA desorption curves also showed reversible binding with repeatable stoichiometry, characteristic for the specific acid tested. ${ }^{34}$ Host $\mathbf{1} \cdot$ pentanoic acid was an amorphous material and displayed a two-step curve, yielding a material that was no longer able to rebind guests.

Table 2. Binding Stoichiometries (1:guest) for the Carboxylic Acid Series

\begin{tabular}{lccc}
\hline \multicolumn{1}{c}{ guest } & obsd weight loss $(\%)$ & 1:guest & guest volume $\left(\AA^{3}\right)$ \\
\hline acetic acid & 10.13 & $1: 1$ & 55 \\
propanoic acid & 8.52 & $3: 2$ & 72 \\
butanoic acid & 7.49 & $2: 1$ & 89 \\
pentanoic acid & 5.60 & $7: 2$ & 105 \\
acrylic acid & 5.36 & $5: 2$ & 54
\end{tabular}

less of the larger propanoic acid is bound relative to $\mathrm{AcOH}$. These observations are consistent with the hypothesis that the guests are bound in the channels of apohost $\mathbf{1}$ and that this confined area can accommodate less of the larger guest.

Ground apohost 1 was similarly equilibrated with propanoic acid vapor to form host $\mathbf{1}$.propanoic acid and shows a PXRD pattern distinct from both apohost $\mathbf{1}$ and host $\mathbf{1} \cdot$ $\mathrm{AcOH}$ (Figure 9b, top). The guest was removed by heating to $120{ }^{\circ} \mathrm{C}$ for $2 \mathrm{~h}$, and the powder was re-examined by PXRD. The evacuated solid showed a well-defined structure (Figure 9b, middle) that closely matched that of apohost $\mathbf{1}$. Finally, upon retreatment of the evacuated ground apohost 1 with propanoic acid vapor, the powder exhibited a PXRD pattern with peak positions and intensities nearly identical to the original host $\mathbf{1}$ propanoic acid structure (Figure 9b, bottom). TGA analysis of this final host $\mathbf{1} \cdot$ propanoic acid powder showed a weight loss of $8.40 \%$, which corresponds to 3:2 binding of propanoic acid. The data shows that apohost 1 can reversibly bind propanoic acid with reproducible stoichiometry. The new inclusion complex, host 1-propanoic acid, has a well-defined structure, and the observed binding ratio does not depend on the surface area, indicating that the guest is bound inside the channels and not absorbed on the surface.

Next, apohost 1 was tested with a series of small linear carboxylic acids, and all were found to be good guests. Apohost 1 formed stable inclusion complexes at room temperature with each of these linear carboxylic acids. Apohost 1 showed selectivity for smaller carboxylic acids and did not bind longer chain carboxylic acids such as heptanoic and octanoic acids. The stoichiometries of the host $\mathbf{1} \cdot$ carboxylic acid inclusion compounds could be readily calculated from

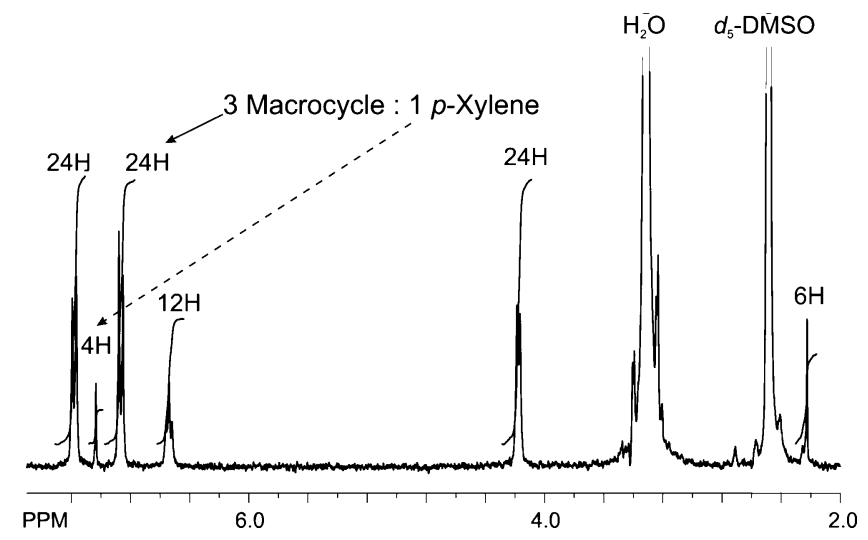

Figure 11. ${ }^{1} \mathrm{H}$ NMR in $\mathrm{d}_{6}$-DMSO after crystalline apohost 1 was equilibrated with a mixture of $o-, m$-, $p$-xylenes. Only peaks corresponding to the macrocycle, $p$-xylenes (3:1 cycle:guest), and solvent (DMSO, $\mathrm{H}_{2} \mathrm{O}$ ) were observed. $p$-Xylene signals are at $7.03(4 \mathrm{H})$ and $2.20 \mathrm{ppm}(6 \mathrm{H})$.

TGA desorption curves. Figure 10 shows TGA desorption curves for a series of low-molecular-weight carboxylic acids (acetic, propanoic, butyric, pentanoic, and acrylic acids). Each host $\mathbf{1} \cdot$ carboxylic acid complex displayed a different and characteristic weight loss. From the percent weight loss as measured by TGA, we calculated the macrocycle:guest stoichiometry for the carboxylic acid series and reported the averaged values in Table 2 for a minimum of three absorption-desorption experiments. ${ }^{34}$ Binding, as measured by the macrocycle:guest stoichiometry, decreased with increasing size of the guest, consistent with the guests binding in a confined environment. This decrease correlates well with guest volume, with the smallest acid (acetic) binding at the highest ratio (1:1 macrocycle:guest) and the largest (pentanoic) showing the lowest binding (7:2 macrocycle:guest). Conjugated acrylic acid was found to bind in 5:2 ratio (macrocycle:guest), which was less than expected given its calculated volume; however, this may be due to the different shape presented by the conjugated acid versus the simple carboxylic acids. Binding ratios steadily decreased with increasing guest volume (Table 2), suggesting that there is some size selectivity occurring as the guests absorb into a well-defined cavity. Each acid bound with a distinct stoichiometry that was repeatable for multiple (3-8) absorption-desorption cycles. ${ }^{34}$

We investigated the absorption properties of apohost $\mathbf{1}$ with alkanes on the basis of previously published results that crystalline urea may be used to separate linear from branched alkanes via encapsulation (clathrates). ${ }^{35}$ Urea forms regular porous networks around long chain alkanes with the alkanes filling the center of the linear, parallel urea tunnels. Apohost $1 \mathrm{did}$ not form inclusion complexes with any of the alkanes tested. No significant binding of alkanes was detected by ${ }^{1} \mathrm{H}$ NMR and TGA. ${ }^{36}$ We conclude that apohost 1 preferentially binds polar guests and that the nonpolar alkanes are

(34) Table 2 reports the average binding stoichiometry for a minimum of three absorption-desorption experiments. The exact number of binding experiments measured was 71 for acetic acid, 8 for propanoic acid, 8 for butanoic acid, 3 for pentanoic acid, and 4 for acrylic acid.

(35) (a) Smith, A. E. Acta Crystallogr. 1952, 5, 224. (b) Palacin, S.; Chin, D. N.; Simanek, E. E.; MacDonald, J. C.; Whitesides, G. M.; McBride, M. T.; Palamore, G. T. R. J. Am. Chem. Soc. 1997, 119, 11807. (c) Lovinger, A. J.; Nuckolls, C.; Katz, T. J. J. Am. Chem. Soc. 1998 , 120, 264. (d) Harris, K. D. M. J. Chem. Soc. Rev, 1997, 26, 279. 

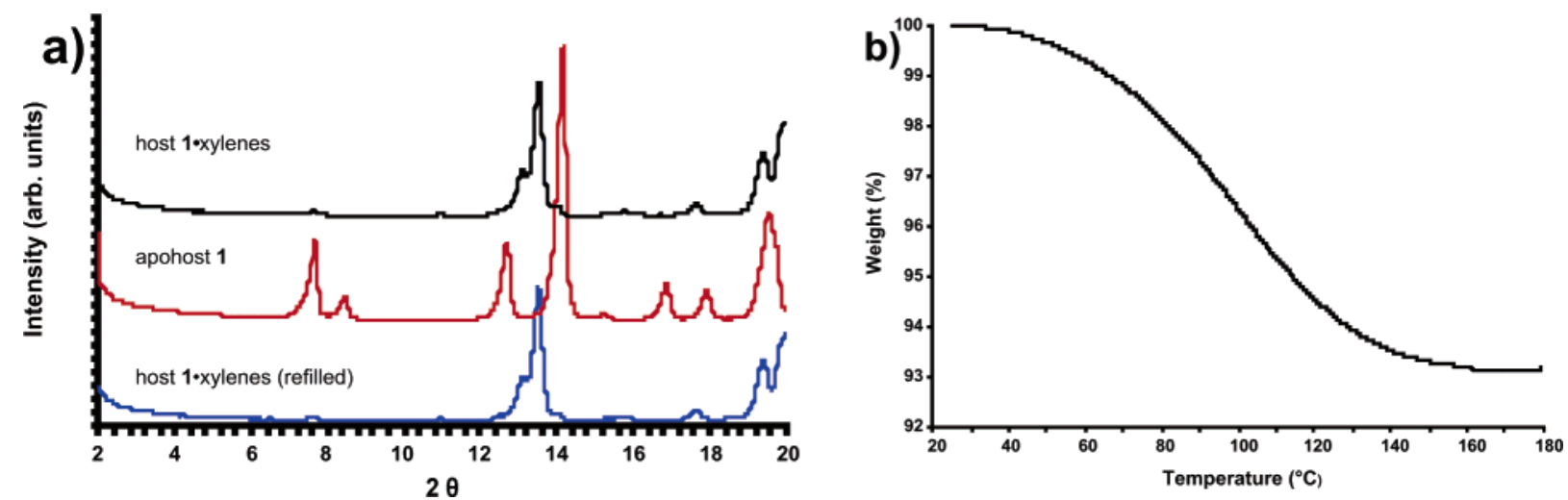

Figure 12. (a) PXRD patterns for host $\mathbf{1} \cdot x y l e n e s$ (top), apohost $\mathbf{1}$ after xylene removal (middle), and host $\mathbf{1} \cdot x y l e n e s$ refilled (bottom). (b) TGA desorption curve of host $1 \cdot x y l e n e s$.

$3: 3$

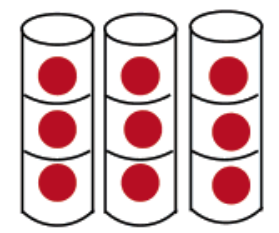

filled host $1 \cdot \mathrm{AcOH}$

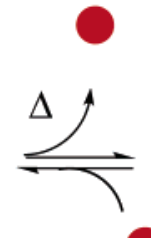

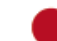

Figure 13. Schematic of guest absorption and desorption.

either not absorbed or alternatively bind with very low affinity and desorb well below room temperature. It is likely that the polarizable phenyl ether structure of the macrocycle together with the urea groups create a polar interior that has higher affinity for polar guests.

Research on the carboxylic acid series indicated that size and shape play a role in determining binding stoichiometry. The narrow channels of apohost $\mathbf{1}$ should be able to differentiate molecules on the basis of shape. The $o-, m-$, and $p$-xylene isomers offered a simple binding competition experiment to test shape selectivity. Molecular modeling using Macromodel indicated that the constrained channel should be highly shape selective for the more linear para isomer in comparison to the bent ortho and meta derivatives. ${ }^{30}$ In fact the $p$-xylene isomer is similar in shape to the slightly larger $\mathrm{AcOH}$ dimer, although the xylene has a lower polarity as estimated by dielectric constant $(\epsilon)$. The $\pi^{*}$ solvent scale, based on the ability of a solvent to stabilize ionic or polar species, gives a measure of nonspecific electrostatic solvation and estimates that the $p$-xylene $(0.45)$ is in fact more similar to acetic acid (0.64) than it is to $n$-hexanes $(-0.11) .{ }^{37}$ The crystalline apohost 1 was exposed to a mixture of $o^{-}, \mathrm{m}-$, and $p$-xylenes in a sealed chamber at room temperature. All three isomers have the same vapor pressures and should be equally available in the vapor phase. The crystals were dissolved in $\mathrm{d}_{6}$-DMSO and examined by ${ }^{1} \mathrm{H}$ NMR (Fig-

(36) A series of alkanes (hexane, heptane, octane, decane, dodecane, undecane, dodecane, trydecane, and tetradecane) were tested with the host; however, none showed significant binding by TGA or ${ }^{1} \mathrm{H}$ NMR The binding ratio for heptane was typical for the alkane series (28:1 macrocycle:heptane).

(37) (a) Kamlet, M. J.; Abboud, J. L.; Taft, R. W. J. Am. Chem. Soc. 1977, 99, 6027. (b) Taft, R. W.; Abboud, J. L.; Kamlet, M. J. J. Am. Chem. Soc. 1981, 103, 1080-1086. (c) Catalan, J. J. Org. Chem. 1995, 60, 8315. ure 11). The binding ratio was followed for 1-7 days and appeared to reach an equilibrium by 4 days. Only proton resonances corresponding to the $p$-xylenes and the macrocycle were observed and the stoichiometry at equilibrium corresponded to 3:1 (macrocycle:guest). Calculation of binding stoichiometry from the TGA desorption curve (Figure $12 \mathrm{~b}$ ) also corresponded to 3:1 binding stoichiometry.

The absorption-desorption process could also be followed by PXRD (Figure 12). Ground apohost 1 was similarly equilibrated with a mixture of $o-, m$-, and $p$-xylenes to form host 1•xylenes and showed a PXRD pattern distinct from both apohost $\mathbf{1}$ and other host $\mathbf{1} \cdot$ complexes (Figure 12a, top). The evacuated solid showed a well-defined structure (Figure $12 \mathrm{a}$, middle) that closely matched that of apohost $\mathbf{1}$. Finally, upon retreatment of the evacuated ground apohost 1 with xylenes vapor, the powder exhibits a PXRD pattern with peak positions and intensities nearly identical to the original host 1·xylenes structure. As a control, we equilibrated the host separately with each xylene isomer. No binding was observed for either the $o$ - or $m$-xylene, and $p$-xylene was bound in a 3:1 ratio by both ${ }^{1} \mathrm{H}$ NMR and TGA. This strong preference of apohost $\mathbf{1}$ for the para isomer suggests experimentally that these guests are bound inside the channels instead of on the surface.

These studies lead us to postulate a simple binding schematic (Figure 13). First, the AcOH guest in filled host 1 $\mathrm{AcOH}$ can be removed by heating to form a robust apohost 1, which has remarkable solid-gas molecular recognition properties. Apohost $\mathbf{1}$ can absorb a new guest vapor to give a second inclusion complex. Heating releases this second guest, thereby returning to apohost $\mathbf{1}$ structure that can readsorb $\mathrm{AcOH}$ and reform host $\mathbf{1} \cdot \mathrm{AcOH}$. To test if the structural framework of apohost $\mathbf{1}$ is retained after the 


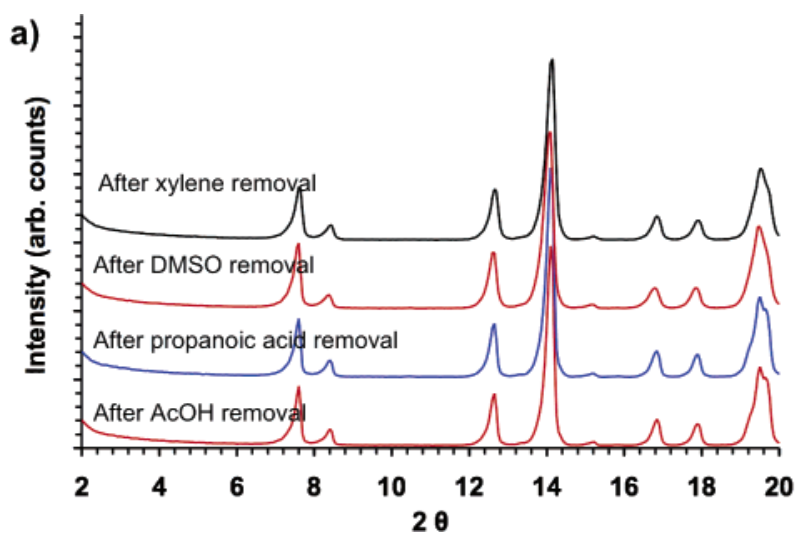

b)

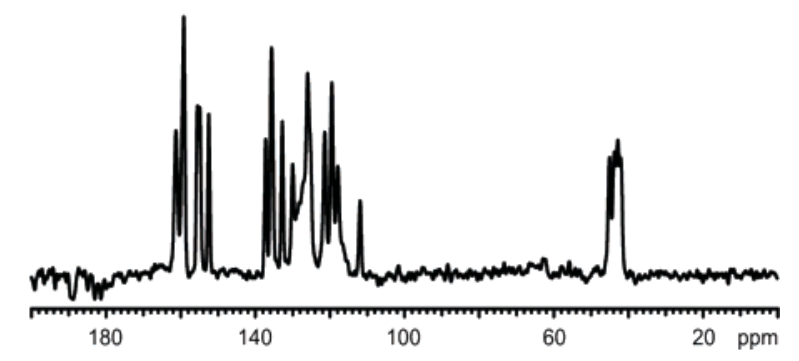

Figure 14. (a) Comparison of the PXRD patterns for apohost $\mathbf{1}$ formed after removal of a variety of guest molecules from host $\mathbf{1} \cdot$ guest. (b) Ramped ${ }^{13} \mathrm{C}\left({ }^{1} \mathrm{H}\right)$ CP-MAS NMR spectra for the crystalline apohost $\mathbf{1}$.

removal of different guests, we compared the structure of the apohosts by PXRD. Figure 14a shows a comparison of the four apohosts formed upon removal of $\mathrm{AcOH}$, propanoic acid, xylenes and dimethyl sulfoxide which was previously reported to be a guest for apohost $1{ }^{8}$ Each of these guests forms a highly ordered inclusion complex with apohost $\mathbf{1}$ and gives a PXRD pattern distinct from apohost $\mathbf{1}$. Heating removes the guest, reforming apohost $\mathbf{1}$. Examination of each apohost by PXRD gave patterns with closely matched peak positions and intensities, indicating that the structure of apohost $\mathbf{1}$ is retained. This highly ordered apohost also gives a sharp ramped ${ }^{13} \mathrm{C}\left({ }^{1} \mathrm{H}\right) \mathrm{CP}$-MAS NMR spectra, displaying four resonances for the methylene carbons, 12 aromatic carbons, and two carbonyls (Figure 14b). This is due to the crystal environment, as the phenyl groups are no longer equivalent; one is positioned approximately planar to the plane of the macrocycle and the other is tilted to give a more favorable edge to face aromatic stacking interaction. Yet, DMSO, an aggressive hydrogen-bonding solvent, breaks up the assembled structure, and dissolving these crystals in $\mathrm{d}_{6}$-DMSO gives ${ }^{1} \mathrm{H}$ and ${ }^{13} \mathrm{C}$ NMR solution spectra that match those of monomeric macrocycle $\mathbf{1}$.

In summary, the inclusion complex, filled host $\mathbf{1} \cdot \mathrm{AcOH}$, formed by the self assembly of bis-urea macrocycle $\mathbf{1}$ in $\mathrm{AcOH}$ can be evacuated completely of guests to form a robust apohost $\mathbf{1}$ that displays a gas adsorption isotherm consistent with that of a microporous material. This apohost has a remarkable ability to bind and exchange guest molecules from the vapor phase. A series of guests, including carboxylic acids, alkanes, and aromatics were tested. Polar, linear carboxylic acids were found to form the stable inclusion complexes, whereas no binding was observed for nonpolar alkanes. Apohost 1 displays binding selectivity by shape exclusion, preferentially binding $p$-xylene from a mixture of xylene isomers. We can begin to rationalize the affinity and selectivity of guests binding in apohost $\mathbf{1}$ on the basis of the size, shape, and polarity of the guests. Together, these observations show that self-assembled bis-urea macrocycles form robust porous structures that can selectively and reversibly bind guests. We are now focusing on the mechanism and kinetics of this solid-gas binding event and hope to report on this in due course.

Acknowledgment. This work was supported by the NSF (CHE-0316424) and by the University of South Carolina. We thank Professor Hans-Conrad zur Loye for generous use of his TGA and PXRD instruments.

Supporting Information Available: ${ }^{1} \mathrm{H}$ NMR spectra of apohost $\mathbf{1}$ and host $\mathbf{1} \cdot \mathrm{AcOH}$, and additional distances between van der Waals surfaces of pore-defining atoms of host $\mathbf{1} \cdot \mathrm{AcOH}$ are shown. SEM images of the ground-filled host $\mathbf{1} \cdot \mathrm{AcOH}$ and apohost 1. A plot comparison of the observed $\mathrm{CO}_{2}$ adsorption isotherm of apohost 1 at $0{ }^{\circ} \mathrm{C}$ with the isotherm calculated by NLDFT method and BET plot for the $\mathrm{CO}_{2}$ adsorption at $-78^{\circ} \mathrm{C}$. This material is available free of charge via the Internet at http://pubs.acs.org.

CM0614057 